\title{
Clonal Expansion of Verticillium dahliae in Lettuce
}

\author{
S. Gurung, D. P. G. Short, Z. K. Atallah, and K. V. Subbarao
}

Department of Plant Pathology, University of California, Davis, c/o U.S. Agricultural Research Station, 1636 E. Alisal Street, Salinas 93905. Current address of third author: Hartnell College, 411 Central Avenue, Salinas, CA 93901.

Accepted for publication 17 January 2014.

\section{ABSTRACT}

Gurung, S., Short, D. P. G., Atallah, Z. K., and Subbarao, K. V. 2014. Clonal expansion of Verticillium dahliae in lettuce. Phytopathology 104:641-649.

Few studies in population biology have documented how structure and diversity of pathogens evolve over time at local scales. With the historical samples of Verticillium dahliae available from lettuce, we investigated the structure and diversity of this pathogen in time and space. Three hundred twenty-nine $V$. dahliae isolates from lettuce fields collected over 18 years were characterized with polymorphic microsatellite markers and polymerase chain reaction tests for race and mating type. Genetic variation within and among commercial lettuce fields in a single season was also investigated using an additional 146 isolates. Sixty-two haplotypes (HTs) were observed among the 329 isolates. A single HT was frequently observed over multiple years and locations (61.40\%). Genetic diversity, allelic richness, and private allelic richness suggested a relatively recent clonal expansion. Race 1 (93.63\%) and MAT1-2-1 (99.69\%) were overwhelmingly represented among the isolates. Linkage disequilibrium was significant $(P<0.001)$ for all populations, suggesting limited sexual recombination in the sampled populations from lettuce. Populations from 2006, 2009, and 2010 had higher numbers of unique HTs, implying a recent introduction of novel HTs. We conclude that $V$. dahliae population from lettuce evaluated in this study is expanding clonally, consistent with an asexually reproducing pathogen, and the movement of clonal genotypes locally occurs over time.
The Salinas Valley in California is the most important lettuce production area in the United States and accounted for $63.33 \%$ of in-state production and $50.66 \%$ of the U.S. production in 2011 $(3,4)$. The estimated farmgate value of all types of lettuce in Monterey County alone was over $\$ 1.23$ billion in 2011 (4). The remaining lettuce production in the state occurs in the Santa Clara, Santa Maria, and San Juan valleys during the spring and summer, while winter production is concentrated in the San Joaquin and Imperial valleys.

Verticillium dahliae is a destructive soilborne pathogen that causes Verticillium wilt in many economically important crops including lettuce $(5,31,35)$. The disease becomes acute when the melanized resting structures produced by the pathogen called microsclerotia become established and increase in soil over time. Losses vary in different crops, but the disease has been unusually severe on lettuce with yield losses of up to $100 \%$ routinely recorded (35) and densities of microsclerotia of up to 2,500 microsclerotia $\mathrm{g}^{-1}$ of soil observed (7). Since the first report of Verticillium wilt in lettuce in 1995 in a single field (35), the disease has spread to multiple fields in coastal California. As of 2010, Verticillium wilt was confirmed in more than 175 commercial fields covering an area of nearly 1,600 ha from disease surveys and soil assays (5). Since then, growers have reported Verticillium wilt in additional lettuce fields throughout the Salinas Valley and, thus, the disease poses a major threat to lettuce production in coastal California.

First two authors contributed equally to this work.

Corresponding author: K. V. Subbarao; E-mail address: kvsubbarao@ucdavis.edu

* The $\boldsymbol{e}$-Xtra logo stands for "electronic extra" and indicates that the online version contains three supplementary tables.

http://dx.doi.org/10.1094/PHYTO-10-13-0282-R

(c) 2014 The American Phytopathological Society
In heavily infested fields that suffer near-total yield losses, one option available to growers is to fumigate infested fields with methyl bromide and chloropicrin to reduce the number of microsclerotia in soil followed by rotation to strawberries to recover the cost of fumigation. However, consecutive lettuce crops following strawberries return the soil microsclerotial numbers to prefumigation levels, rendering fumigation inevitable once again (41). Other management options potentially available include rotating to nonhost vegetables, planting tolerant types of lettuce, and growing short-cycle baby lettuce crops, but the economics of crop production in the area preclude these options sometimes. Because of the harmful effects of some fumigants on the environment, and the escalating cost of fumigation and uncertainty over their continued availability and use, development of lettuce cultivars resistant to $V$. dahliae remains the most feasible and environmentally sustainable option for controlling Verticillium wilt in lettuce. Efforts are currently underway to breed resistance into lettuce cultivars $(21,22)$.

Identifying pathogen genotypes present in a given area over time is essential because breeders must test their material against known pathogen variants (30). Thus, a necessary prerequisite to deploy durable host resistance and minimize the erosion of cultivar resistance against $V$. dahliae is knowledge of the spatial and temporal pathogen population structure (26). The availability of historical population samples of $V$. dahliae from the initial outbreak of Verticillium wilt in Watsonville (Santa Cruz County) and historical and contemporary samples of $V$. dahliae from the Salinas Valley offered a unique opportunity to determine the extent of temporal and spatial genetic variation in $V$. dahliae populations from lettuce.

Previous findings have revealed the significance of clonal expansion and migration of genotypes in $V$. dahliae $(6,16)$. Europe is a plausible center of $V$. dahliae diversity based on the level of diversity found in the populations from Italy and Denmark (unpublished data). V. dahliae carried in spinach seed produced in Denmark, New Zealand, The Netherlands, and Washington State has been associated with wilt in lettuce commonly rotated with 
spinach (15). This is further supported by the lack of population differentiation among $V$. dahliae from various hosts commonly grown in coastal California $(4,8)$. In addition, Atallah et al. $(6,7)$ showed that migration of $V$. dahliae in spinach seed imported from Denmark and Washington plays a major role in shaping the population structure of $V$. dahliae in coastal California lettuce. However, only limited information is available on the within- and between-field variation in $V$. dahliae genetic diversity.

Two pathogenic races exist in $V$. dahliae from lettuce and tomato (39). Race 1 can only cause disease in lettuce cultivars lacking the gene $V r l$, whereas race 2 can break the resistance governed by $\operatorname{Vrl}(21,39)$. Both races may be recovered from crops in coastal California. In a small set of $V$. dahliae isolates from lettuce $(N=31)$, Atallah et al. (8) detected race 1 and race 2 in a 3:1 ratio, respectively.

$V$. dahliae is a heterothallic fungus (37) with the two mating type idiomorphs, MAT1-1-1 and MAT1-2-1, identified in isolates from several hosts $(23,37,38)$. Usami et al. (38) found that $20 \%$ of $V$. dahliae isolates from lettuce seeds were MAT1-1-1, and we detected MAT1-1-1 isolates from spinach seeds (unpublished data), a crop which is frequently rotated with lettuce. Information on the frequency of mating types in $V$. dahliae populations from lettuce and other crops is unavailable and this information is critical to understanding the potential sexual cycle in the fungus.

The objectives of this study were to (i) determine the temporal frequencies of specific multilocus haplotypes (HTs), races, and mating types in $V$. dahliae populations from commercial lettuce fields over an 18-year period; (ii) investigate genetic variation in $V$. dahliae from within and between fields sampled in single seasons; and (iii) investigate potential changes in $V$. dahliae populations from commercial lettuce fields and novel introductions of V. dahliae genotypes between 1995 and 2013.

\section{MATERIALS AND METHODS}

Sampling of isolates and DNA extraction. The $V$. dahliae isolates used in this study were collected over an 18-year period that spanned from 1995, when the disease was first discovered on lettuce, to 2013 in coastal California (Supplementary Table 1). The samples collected during 1995 and 1996 from Watsonville, Santa Cruz County and during 1999 from Salinas, Monterey County represent the first ever recorded Verticillium wilt in lettuce. Each year, $V$. dahliae was collected from 1 to 10 fields during disease surveys (Table 1). The sample processing and isolate collection procedures are described below.

In separate collections, three lettuce fields with a history of Verticillium wilt were selected in Salinas during 2009 and 2010 to perform fine scale spatial structure analyses on $V$. dahliae populations (Supplementary Table 2). A systematic hierarchical sampling method was employed for isolate collection from these fields using sampling grids $\left(25 \times 25 \mathrm{~m}^{2}\right)$. Within each field, one diseased plant was collected at random and additional plant collections followed the sampling pattern described here: (i) a plant next to the infected plant in the same bed; (ii) a plant in the adjacent bed; (iii) an adjacent plant in the same row; (iv) a plant $1 \mathrm{~m}$ away within the row; (v) a plant $3 \mathrm{~m}$ away within the row; (vi) a plant $5 \mathrm{~m}$ away within the row; and (vii) a plant $10 \mathrm{~m}$ away within the row.

The outer epidermal and cortical layers were excised from the tap roots of symptomatic lettuce plants with a sterilized knife and surface sterilized with 5\% sodium hypochlorite. Two to three small pieces of the surface-sterilized tissue were plated on NP-10 medium and incubated in the dark at room temperature $(23 \pm$ $\left.2{ }^{\circ} \mathrm{C}\right)$. V. dahliae colonies that developed were then transferred to potato dextrose agar and single spore isolates were obtained. Two or three agar disks (3-mm-diameter) from fresh cultures of single spore isolates were transferred to $50 \mathrm{ml}$ of potato dextrose broth in conical flasks. Mycelium was harvested following incubation for 10 to 12 days, washed with sterilized distilled water, dried using paper towels, and placed in $2 \mathrm{ml}$ tubes and stored at $-80^{\circ} \mathrm{C}$ for later use. For DNA extraction, mycelia were lyophilized and ground to a fine powder using a high-speed mixer mill (Model MM301; Retsch Inc., Newtown, PA). A FastDNA Kit (MP Biomedicals, LLC, Solon, $\mathrm{OH}$ ) was used to extract genomic DNA from $V$. dahliae and the quality and quantity of each DNA was assessed using a Nano Drop (Model ND-1000, Thermo Scientific Inc., Waltham, MA). The DNA of each isolate was adjusted to 10 $\mathrm{ng} / \mu \mathrm{l}$ for all polymerase chain reactions (PCR).

Verticillium species-specific primers. DNA from all isolates was tested with a previously developed Verticillium species-specific PCR assay (24) and only the isolates identified as $V$. dahliae were used for further analyses. Briefly, PCR was performed in 25- $\mu \mathrm{l}$ reactions using GoTaq Green Mastermix (Promega, Madison, WI) in a PTC-100 Peltier Thermal cycler (MJ Research, Inc., Waterman, MA) that was programmed for $5 \mathrm{~min}$ at $94^{\circ} \mathrm{C}$ for initial denaturation, 30 cycles consisting of $30 \mathrm{~s}$ at $94^{\circ} \mathrm{C}, 30 \mathrm{~s}$ at $58^{\circ} \mathrm{C}$, and $1 \mathrm{~min}$ at $72^{\circ} \mathrm{C}$, followed by a final $7 \mathrm{~min}$ extension at $72^{\circ} \mathrm{C}$. For each PCR amplicon, $6 \mu$ of SyberGold (Invitrogen, Carlsbad, CA) was added and later separated in $1.5 \%$ (wt/vol) agarose gels in $0.5 \%$ TBE buffer $(0.089 \mathrm{M}$ Tris-borate, $0.089 \mathrm{M}$ boric acid, and $0.002 \mathrm{M}$ EDTA). Gels were run for approximately 1.5 to $2 \mathrm{~h}$ at $75 \mathrm{~V}$ and visualized with a transilluminator (UVP, Upland, CA). A 100-bp DNA ladder (Invitrogen, Carlsbad, CA) was used as a size marker on each gel and previously identified $V$. dahliae isolate Ls17 was included as a reference isolate in each gel.

Mating type determination. Mating type was determined using a multiplex PCR assay with primers designated to amplify the MAT1-1-1 and MAT1-2-1 idiomorphs of V. dahliae as described previously $(23,37)$. The primer pair Alf3: 5'-CGATCGC GATATCGGCAAGG-3' (forward) and MAT11r: 5'-CAGTCAG ATCCAACCTGCTGGCC-3' (reverse) amplified a 600-bp fragment from MAT1-1-1 isolates, and the primer pair HMG21f: $5^{\prime}$ CGGCCGCCCAATTCGTACATCC-3' (forward) and MAT21r: 5'-CATGCCTTCCATGCCATTAGTAGCC-3' (reverse) amplified a 300-bp fragment from MAT1-2-1 isolates. All primers were used in equal concentrations in a single PCR. Briefly, a total of $25 \mu \mathrm{l}$ of mixture was prepared per DNA sample that contained $10.5 \mu \mathrm{l}$ of sterile deionized distilled water, $2 \mu \mathrm{l}$ of genomic DNA at $10 \mathrm{ng} / \mu \mathrm{l}$, $12.5 \mu \mathrm{l}$ of $2 \times$ GoTaq master mix. The PCR mixtures with $2 \mu \mathrm{l}$ of sterile distilled water devoid of a DNA template were used as negative controls. Each PCR had 35 cycles of the following thermal profile: $1 \mathrm{~min}$ at $94^{\circ} \mathrm{C}$ for initial denaturation, $30 \mathrm{~s}$ at $57^{\circ} \mathrm{C}$ for annealing, $1 \mathrm{~min}$ at $72^{\circ} \mathrm{C}$ for extension, and a final $10 \mathrm{~min}$ extension at $72^{\circ} \mathrm{C}$. PCR amplicons were visualized as above.

Determination of $\boldsymbol{V}$. dahliae race structure. The effector gene Avel has been well characterized in $V$. dahliae race 1 isolates (13). The primers VDAve1F and VDAve1R were used to determine the presence of Avel in $V$. dahliae isolates, as previously described $(12,13)$. Similarly, we also characterized the race 2 isolates in lettuce $V$. dahliae populations using the race 2 -specific primers (34). The PCR reactions for races 1 and 2 were conducted separately. Briefly, each $25-\mu \mathrm{l}$ PCR reaction contains $2 \mu \mathrm{l}$ of genomic DNA at $10 \mathrm{ng} / \mu \mathrm{l}, 12.5 \mu \mathrm{l}$ of $2 \times$ GoTaq master mix (Promega), $10 \mu \mathrm{l}$ of sterile distilled water, and $1 \mu \mathrm{l}$ of each primer at a concentration of 5 pmol. For race 1, each PCR had the following thermal profile: $2 \mathrm{~min}$ at $94^{\circ} \mathrm{C}$ for initial denaturation, followed by 35 cycles of $30 \mathrm{~s}$ at $94^{\circ} \mathrm{C}, 45 \mathrm{~s}$ at $62^{\circ} \mathrm{C}$, and $1 \mathrm{~min}$ at $72^{\circ} \mathrm{C}$ followed by a final extension of $10 \mathrm{~min}$ at $72^{\circ} \mathrm{C}$. For race 2 , each PCR had the following thermal profile: 2 min at $94^{\circ} \mathrm{C}$ for initial denaturation, followed by 35 cycles of $1 \mathrm{~min}$ at $94^{\circ} \mathrm{C}, 1 \mathrm{~min}$ at $64^{\circ} \mathrm{C}$, and $1 \mathrm{~min}$ at $72^{\circ} \mathrm{C}$ followed by a final extension of $10 \mathrm{~min}$ at $72^{\circ} \mathrm{C}$.

Microsatellite genotyping. Thirteen previously described, highly polymorphic microsatellite markers (VD1, VD2, VD3, VD8, VD9, VD10, VD11, VD12, VD27, VD69, VD73, VD92, and VD97) were used for this study $(6,7)$. These markers were 
developed from the whole genome sequence of $V$. dahliae isolate Ls17 (www.broadinstitute.org) (2). Briefly, PCR was performed in $25 \mu \mathrm{l}$ total volumes containing $6.5 \mu \mathrm{l}$ of sterile distilled water, $2 \mu \mathrm{l}$ of genomic DNA at $10 \mathrm{ng} / \mu \mathrm{l}, 2 \mu \mathrm{l}$ of $4 \mu \mathrm{M}$ each reverse and forward primer, and $12.5 \mu \mathrm{l}$ of GoTaq Green PCR mix (Promega). PCR was carried out in PTC-100 Peltier Thermal cycler (MJ Research, Inc., Waterman, MA) that was programmed for 5 min at $94^{\circ} \mathrm{C}$ for initial denaturation and 34 cycles consisting of $30 \mathrm{~s}$ at $95^{\circ} \mathrm{C}, 20 \mathrm{~s}$ at $55^{\circ} \mathrm{C}$, and $30 \mathrm{~s}$ at $72^{\circ} \mathrm{C}$, followed by a final $10 \mathrm{~min}$ extension at $72^{\circ} \mathrm{C}$. The PCR amplicons labeled with different fluorophores (FAM, HEX, TAMRA, and ROX) were pooled by adding $2 \mu \mathrm{l}$ of each labeled PCR product into a 96-well PCR plate and sent to the University of California, Davis, DNA Sequencing Facility for further analysis. At the sequencing facility, $1 \mu \mathrm{l}$ of this multiplex mixture was combined with Hi-Di formamide and $0.3 \mu \mathrm{l}$ of LIZ-500 size standard and then separated on an ABI 3100 capillary electrophoresis genetic analyzer (Applied Biosystems, Carlsbad, CA). The GeneMarker software (SoftGenetics, State College, PA) was used to determine the peaks for each fragment. The $V$. dahliae isolate Ls17, for which allele sizes are known for all of the 13 microsatellite markers used in this study was kept as a positive control for each PCR and also included in each 96-well PCR plate to ensure consistency between plates.

Population genetic analyses of $V$. dahliae from 1995 to 2013. $V$. dahliae isolates with identical allelic profiles for all 13 microsatellite loci were considered clones. Clone corrected data sets were used when appropriate. For analyses of temporal variation, populations were defined as isolates collected during the same year (1995 to 2013). Calculations of gene diversity $(H)$ were performed using POPGENE version 1.32 (29,42). The clonal fraction observed within each populations was calculated as $1-$ [(number of different haplotypes)/(total number of isolates)] (43). Allelic richness (average number of alleles per locus) and private allelic richness were computed using a software ADZE (36). This program analyzes allelic diversity by adjusting differences in sample size present between populations using the rarefaction procedure (36). Allelic richness was analyzed with a standard sample size equal to the smallest number of observations per population (14). Due to low sample sizes in certain years, gene diversity, genotypic richness, allelic richness, private allelic richness, and linkage disequilibrium were not calculated for any populations with less than four distinct genotypes.

A Bayesian model-based clustering method implemented in the software program STRUCTURE 2.2, was used to determine the population structure and cluster assignment of each $V$. dahliae isolate (32). Five independent runs were performed for each value of $K$, which ranged from 1 to 10 . Each run consisted of a burn-in period of 10,000 iterations and a length of 100,000 replicates. The result files from STRUCTURE runs were compressed in a .ZIP file and uploaded to the STRUCTURE HARVESTER website (http://taylorO.biology.ucla.edu/structureHarvester/) to determine the most probable number of clusters (17). Results were graphically plotted using the software DISTRUCT (33). Hypothetical evolutionary relationships among the $V$. dahliae HTs were plotted using the goeBURST algorithm implemented in PhyloViz (19). This program uses the allelic profiles of each isolate and uses the algorithm to show the hypothetical relationship of these multilocus types through the unrooted tree-network $(18,19)$.

For each population, multilocus linkage disequilibrium $(L D)$ was assessed by calculating the standardized index of association (rBarD) (1) using MULTILOCUS program version 1.3 (1). An $r B a r D$ value can range from 0 to 1 , where 0 indicates a random association of alleles at different loci and is associated with sexual recombination and an $r$ BarD value of 1 indicates a nonrandom association of alleles at different loci and is associated with asexual reproduction. The significance of each $r$ BarD value was evaluated with 999 randomizations of the data and by comparing the observed and expected values under the null hypothesis of $r B a r D=0$.

Spatial population genetic analyses of $\boldsymbol{V}$. dahliae. To determine the within- and between-field genetic variation among $V$. dahliae isolates collected from three commercial lettuce fields during the same season, isolates from each field were treated as separate populations. Clonal fraction, gene diversity, allelic richness, private allelic richness, and linkage disequilibrium were calculated as described above for each population.

\section{RESULTS}

Verticillium species identification. The DNA from all isolates used in this study amplified with $V$. dahliae-specific multiplex PCR primers (24). During most years, $V$. dahliae was the only species recovered from lettuce fields. However, isolates of $V$. isaacii $(N=10)$ were occasionally recovered from symptomatic lettuce in Salinas during 2009, 2010, and 2011. These isolates were identified on the basis of amplification with $V$. isaaciispecific PCR primers (24) and were excluded from this study.

Distribution of mating types and races of $V$. dahliae in lettuce 1995 to 2013. As expected, a single amplicon matching either MAT1-1-1 or MAT1-2-1 allele was detected in each isolate. Of the total 329 isolates collected during 1995 to 2013 from major lettuce growing areas, 328 (99.69\%) isolates were of MAT1-2-1 idiomorph (Table 1). Only isolate Ls977, collected from Watsonville, CA, during 2007 contained the MAT1-1-1 idiomorph. The highly skewed mating type ratio indicates the predominance of the MAT1-2-1 throughout the study region.

Of the total 329 V. dahliae isolates tested, 311 (94.52\%) had the effector gene Avel and were therefore characterized as race 1. DNA from only 18 (5.48\%) V. dahliae isolates amplified with the race 2-specific PCR. Race 1 isolates were recovered every year from 1995 through 2013, indicating that race 1 is much more predominant in lettuce fields in California (Table 1).

Genetic diversity of $V$. dahliae in lettuce 1995 to 2013. A total of 70 alleles were observed among the 13 microsatellite loci. The allele frequencies varied among $V$. dahliae populations and the average number of alleles at each locus was 5.38. The loci VD2, VD73, and VD8, were the most polymorphic (Supplementary Table 3), while VD9 and VD27 were the least polymorphic. In total, 63 unique HTs were detected among the 329 isolates based on unique allelic profiles (Table 1). A single microsatellite type, HT1, was predominant in most populations (61.70\% of all isolates) (Table 2) and was collected as early as 1995 in Watsonville through to 2013 in Soledad in the southern part of the Salinas Valley. The HT1 was present in all years except 1997, 2002, and 2003 (Table 2). Other genotypes that were detected during multiple years and locations were HT2 $(7.90 \%)$, HT9 (2.13\%), HT13 (1.82\%), HT17 (2.13\%), HT31 (2.43\%), and HT32 (1.82\%) (Table 2). Forty-seven HTs were represented by only a single isolate. Novel HTs were observed in each collection year, relative to HTs collected previously. The highest numbers of unique HTs were recovered during 2006 (7/11 HTs), 2009 (6/12 HTs), 2010 (15/26 HTs), and 2011 (7/8 HTs), respectively (Table 2).

The majority of the populations had low gene diversity and a high clonal fraction. The average gene diversity $(H)$ ranged from 0.09 to 0.48 (Table 1). Isolates collected during 2006 had the highest $H$ value (0.48), while those from $1999(H=0.09), 2013$ $(H=0.09)$, and $2004(H=0.14)$ had the lowest $H$ (Table 1$)$ value. In line with these findings, the 2006 population also had the highest allelic richness (2.04) and private allelic richness (0.52) (Table 1). The lowest allelic richness (1.05) was observed in the 2013 population followed by $V$. dahliae from 2012 (1.06) (Table 1). Clonal fractions of the populations ranged from 0.00 to 0.89 (Table 1). The highest clonal fraction was observed in the 2012 (0.88) and $2013(0.89)$ populations. 
Population structure of $V$. dahliae in lettuce during 1995 to 2013. The STRUCTURE analyses revealed that the most likely number of genetic clusters is 2 , using both the likelihood and $\Delta K$ (17) methods (Fig. 1). The majority of isolates showed strong affiliation to one of the two clusters (light gray and dark gray bars in Fig. 1), and very few admixed individuals (individuals with a cluster affiliation less than 0.80), were observed.

The goeBURST analysis revealed that $95.13 \%$ of the total isolates belonged to a single clonal complex (Fig. 2). HT1 was the major clonet within this large clonal complex. The clonet HT1 included $202(61.40 \%)$ of the 329 total V. dahliae isolates and consisted of isolates collected from nearly all sampling years (Table 2, Fig. 2). Six other clonets, HT2, HT9, HT13, HT17, HT31, and HT32, comprised at least six isolates and together comprised $18.23 \%$ of the total isolates (Fig. 2). Sixteen unique HTs were not connected to the large clonal complex with the single locus variant algorithm (Fig. 2).

Linkage disequilibrium of $V$. dahliae in lettuce 1995 to 2013. Following clone correction, only $V$. dahliae samples collected during 2006, 2009, and 2010 had more than 10 HTs and thus, the standardized index of association ( $r$ BarD) was calculated for these populations. All 3 years had significant $(P<0.001)$ linkage disequilibrium values (Table 1). So, none of the populations were in linkage equilibrium, which is the signature of a typically asexually reproducing population.

Population genetic analyses of $\boldsymbol{V}$. dahliae populations within and among lettuce fields. All of the $V$. dahliae isolates $(N=146)$ from the three commercial lettuce fields in Salinas had the effector gene Avel based on PCR assays and thus, were considered race 1. No amplifications occurred with the race 2 -specific primers. Furthermore, all isolates had the MAT1-2-1 mating type idiomorph.

A total of 27 HTs were detected among the isolates and most of these differed only in one to two microsatellite alleles. The clonal fraction values of the three fields were 0.79 (field 1), 0.87 (field 2 ), and 0.80 (field 3), respectively (Table 3). Lower levels of gene diversity, ranging from 0.20 to 0.22 , were observed within the three lettuce field populations (Table 3). The pair-wise genetic identity values $(I)$ were also very high and ranged from 0.992 to 0.998 among the fields (data not shown). Significant $(P<0.001)$ linkage disequilibrium values were observed in each of the three lettuce field populations (Table 3).

\section{DISCUSSION}

This study investigated the temporal and spatial diversity of $V$. dahliae, a destructive soilborne pathogen that causes Verticillium wilt of lettuce and other crops in coastal California and elsewhere. Populations of $V$. dahliae from lettuce evaluated in this study were highly clonal based on both the temporal and fine scale spatial population genetic analyses using microsatellite markers. Low levels of gene diversity and the frequency of dominant HTs in older and more contemporary samples suggested that only a few HTs have successfully established in fields over time. In addition, low levels of gene diversity and population differentiation were observed within and among intensively sampled lettuce fields. The HT1 was the most predominant genotype among $V$. dahliae from lettuce and was recovered in almost all sampling years. Likewise, race 1 and MAT1-2-1 were most predominant among the $V$. dahliae isolates from lettuce.

Knowledge of the temporal population dynamics is important to assess the evolution and pattern of spread (40) of a pathogen, yet, few studies dealing with temporal and fine scale spatial analyses of pathogen populations exist in the literature. The vast majority of population studies are performed at the regional, country or continental scales $(6,9,10)$. Results from such studies are unlikely to yield accurate predictions of the evolutionary course as isolates collected over large and diverse geographical areas may not share a common gene pool (27). Here, we analyzed $329 \mathrm{~V}$. dahliae isolates collected over an 18-year period, as well as $146 \mathrm{~V}$. dahliae isolates from three commercial lettuce fields to determine the fine scale population structure. These collections included isolates from the first ever recorded Verticillium wilt in lettuce (35).

TABLE 1. Summary of the genetic diversity of Verticillium dahliae collected from commercial lettuce fields in California by year collected

\begin{tabular}{|c|c|c|c|c|c|c|c|c|c|c|c|c|c|}
\hline Year & Sample origin & $\begin{array}{l}\text { Number } \\
\text { of fields } \\
\text { sampled }\end{array}$ & $\begin{array}{l}\text { Sample } \\
\text { size }\end{array}$ & $\begin{array}{l}\text { Haplo- } \\
\text { type }\end{array}$ & $\begin{array}{l}\text { Clonal } \\
\text { fraction }^{\mathrm{a}}\end{array}$ & $\begin{array}{l}\text { Genotypic } \\
\text { richness }\end{array}$ & $\begin{array}{c}\text { Gene } \\
\text { diversity }^{\mathrm{c}}\end{array}$ & $\begin{array}{l}\text { Allelic } \\
\text { richness }^{\mathrm{d}}\end{array}$ & $\begin{array}{l}\text { Private } \\
\text { allelic } \\
\text { richness }^{\mathrm{d}}\end{array}$ & $\begin{array}{c}\text { Race } \\
1\end{array}$ & $\begin{array}{c}\text { Race } \\
2\end{array}$ & $\begin{array}{c}\text { MAT-1-1: } \\
\text { MAT1-2 }\end{array}$ & $r B a r D^{\mathrm{e}}$ \\
\hline 1995 & Watsonville, Santa Cruz & 2 & 9 & 2 & 0.78 & 0.25 & NA & $1.19 \pm 0.10$ & $0.05 \pm 0.04$ & 9 & 0 & $0: 9$ & NA \\
\hline 1996 & Watsonville, Santa Cruz & 4 & 4 & 4 & 0.00 & 1.00 & $0.30(0.30)$ & NA & NA & 2 & 2 & $0: 4$ & $0.478^{* *}$ \\
\hline 1997 & Watsonville, Santa Cruz & 1 & 1 & 1 & 0.00 & 0.00 & & NA & NA & 0 & 1 & $0: 1$ & NA \\
\hline 1999 & $\begin{array}{r}\text { Watsonville, Santa Cruz } \\
\text { and Salinas, Monterey }\end{array}$ & 2 & 6 & 4 & 0.33 & 0.60 & $0.09(0.09)$ & $1.23 \pm 0.12$ & $0.07 \pm 0.07$ & 0 & 6 & $0: 6$ & $0.237^{* *}$ \\
\hline 2000 & Salinas, Monterey & 2 & 10 & 3 & 0.70 & 0.22 & NA & $1.09 \pm 0.09$ & $0.05 \pm 0.05$ & 9 & 1 & $0: 9$ & NA \\
\hline 2001 & $\begin{array}{r}\text { Watsonville, Santa Cruz } \\
\text { and Salinas, Monterey }\end{array}$ & 6 & 8 & 5 & 0.38 & 0.57 & $0.19(0.10)$ & $1.88 \pm 0.22$ & $0.25 \pm 0.09$ & 7 & 1 & $0: 4$ & $0.700^{* * *}$ \\
\hline 2002 & Watsonville, Santa Cruz & 1 & 1 & 1 & 0.00 & 0.00 & NA & NA & NA & 0 & 1 & $0: 1$ & NA \\
\hline 2003 & Watsonville, Santa Cruz & 1 & 1 & 1 & 0.00 & 0.00 & NA & NA & NA & 0 & 1 & $0: 1$ & NA \\
\hline 2004 & Watsonville, Santa Cruz & 4 & 7 & 4 & 0.43 & 0.50 & $0.14(0.09)$ & $1.32 \pm 0.12$ & $0.00 \pm 0.00$ & 5 & 2 & $0: 7$ & $0.066^{* *}$ \\
\hline 2005 & Watsonville, Santa Cruz & 3 & 22 & 6 & 0.72 & 0.19 & $0.32(0.11)$ & $1.35 \pm 0.08$ & $0.22 \pm 0.05$ & 21 & 1 & $0: 22$ & $0.580^{* *}$ \\
\hline 2006 & $\begin{array}{r}\text { Watsonville, Santa Cruz } \\
\text { and Salinas, Monterey }\end{array}$ & 10 & 20 & 11 & 0.45 & 0.52 & $0.48(0.35)$ & $2.04 \pm 0.14$ & $0.52 \pm 0.12$ & 14 & 6 & $0: 21$ & $0.561^{* *}$ \\
\hline 2007 & Salinas, Monterey & 2 & 4 & 1 & 0.75 & 0.00 & NA & NA & NA & 4 & 0 & $1: 3$ & NA \\
\hline 2008 & Salinas, Monterey & 1 & 4 & 3 & 0.25 & 0.66 & NA & NA & NA & 3 & 1 & $0: 4$ & NA \\
\hline 2009 & Salinas, Monterey & 1 & 34 & 12 & 0.64 & 0.30 & $0.22(0.11)$ & $1.30 \pm 0.08$ & $0.10 \pm 0.04$ & 23 & 11 & $0: 34$ & $0.154^{* *}$ \\
\hline 2010 & $\begin{array}{r}\text { Watsonville, Santa Cruz } \\
\text { and Salinas, Monterey }\end{array}$ & 2 & 101 & 26 & 0.74 & 0.24 & $0.22(0.11)$ & $1.32 \pm 0.07$ & $0.08 \pm 0.02$ & 101 & 0 & $0: 101$ & $0.063^{* *}$ \\
\hline 2011 & Salinas, Monterey & 2 & 17 & 8 & 0.53 & 0.43 & $0.27(0.25)$ & $1.61 \pm 0.14$ & $0.23 \pm 0.11$ & 10 & 7 & $0: 17$ & $0.305^{* *}$ \\
\hline 2012 & Salinas, Monterey & 2 & 34 & 4 & 0.88 & 0.09 & $0.11(0.02)$ & $1.06 \pm 0.03$ & $0.01 \pm 0.01$ & 34 & 0 & $0: 34$ & $0.109^{* *}$ \\
\hline 2013 & Salinas, Monterey & 2 & 46 & 5 & 0.89 & 0.08 & $0.09(0.01)$ & $1.05 \pm 0.03$ & $0.01 \pm 0.02$ & 46 & 0 & $0: 46$ & $0.145^{* *}$ \\
\hline
\end{tabular}

${ }^{a}$ Clonal fraction was calculated as $1-$ [(number of different haplotypes)/(total number of isolates)] (43).

${ }^{\mathrm{b}}$ Genotypic richness was calculated as (number of unique haplotypes - 1)/(number of total isolates -1 ).

c Unbiased estimate of gene diversity (30).

d Allelic richness and private allelic richness were calculated using Software ADZE that uses rarefaction (36).

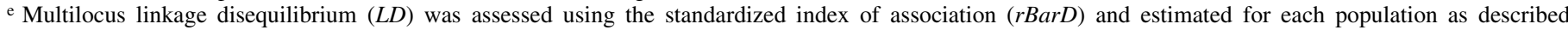
previously (1). The significance of $r B a r D$ was tested with 999 randomizations of the data by comparing the observed value to that expected under the null hypothesis of $r B a r D=0$. The null hypothesis of $L D$ was rejected if $P<0.001$. ** indicates significant at $P=0.001$. 
$V$. dahliae populations in lettuce fields were highly clonal. Two dominant clonets (HT1 and HT2) were frequently recovered over the 1995 to 2012 period. We postulate that of the genetically diverse populations of $V$. dahliae introduced into a new environment and/or host, e.g., lettuce, only a small number of HTs are able to successfully establish and persist. Such bottlenecks explain the observed low levels of genetic diversity. The level of gene diversity observed was lower than that expected for a regularly outcrossing, heterothallic pathogen. However, low levels of gene diversity, hypothesized to be the result of a population bottleneck

TABLE 2. Occurrence and distribution of haplotypes (HTs) of Verticillium dahliae sampled during 1995 to 2013 in commercial lettuce fields in California

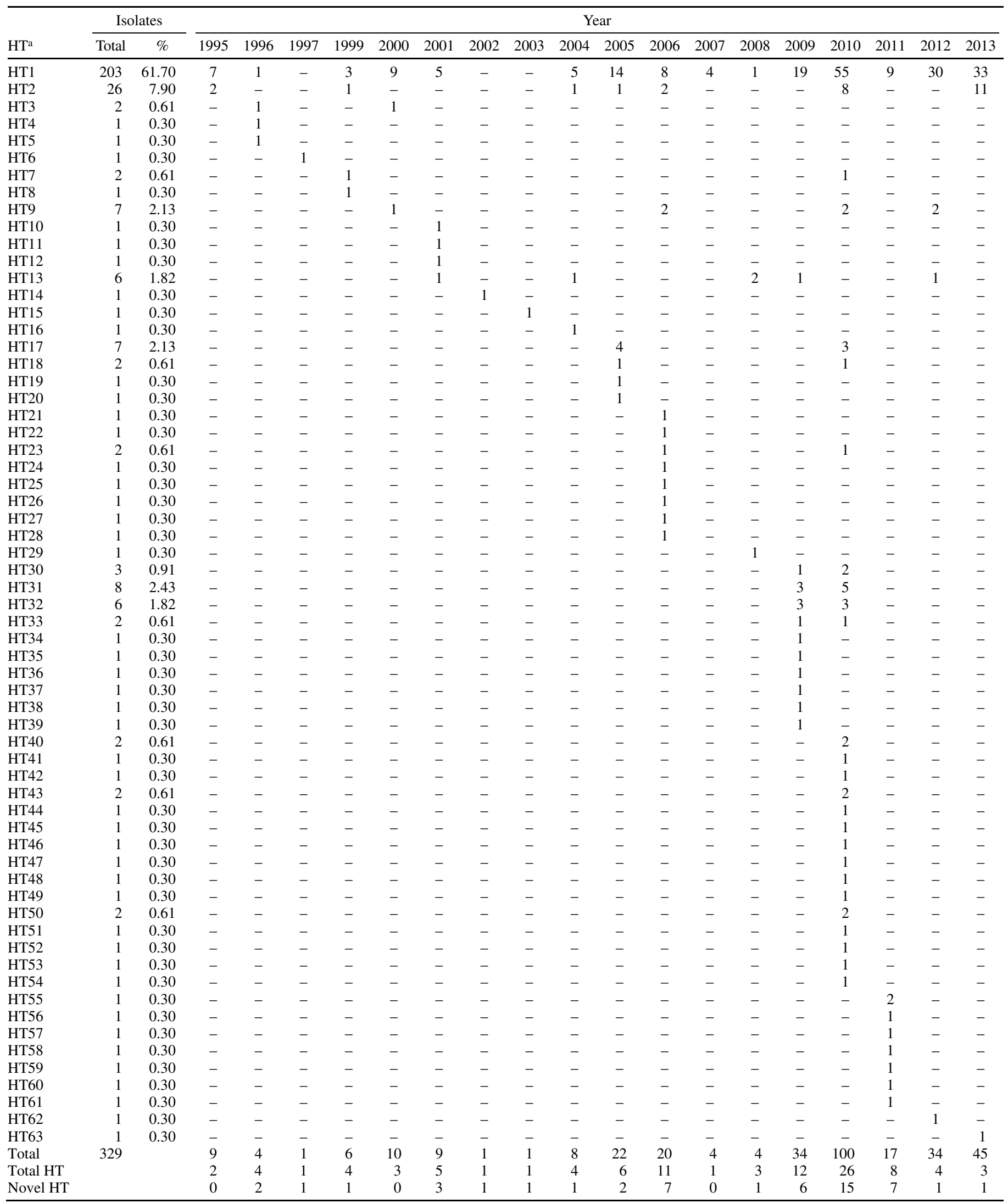


have also been observed in other heterothallic plant pathogens such as Phytophthora cinnamomi, which was introduced into South Africa and Australia (25). In line with the trends observed in the temporal dynamics of $V$. dahliae, low levels of gene diversity were also observed in the three commercial lettuce field populations used for the analyses of fine scale spatial structure. We discovered that the same dominant microsatellite type, HT1, which was first observed in 1995, was also the most predominant HT within the three lettuce fields in Salinas. In total, we detected
26 HTs from these three commercial lettuce field populations, though most of the HTs differed only at one or two microsatellite loci. The overall genetic diversity in $V$. dahliae populations from lettuce fields appears to be limited, suggesting a relatively recent clonal expansion. Clonal expansion of $V$. dahliae populations in lettuce was also supported by STRUCTURE and goeBURST analyses. We detected two genetic clusters using STRUCTURE, and both clusters were strongly inferred based on the multilocus haplotypes, without regard for the geographical location of iso-

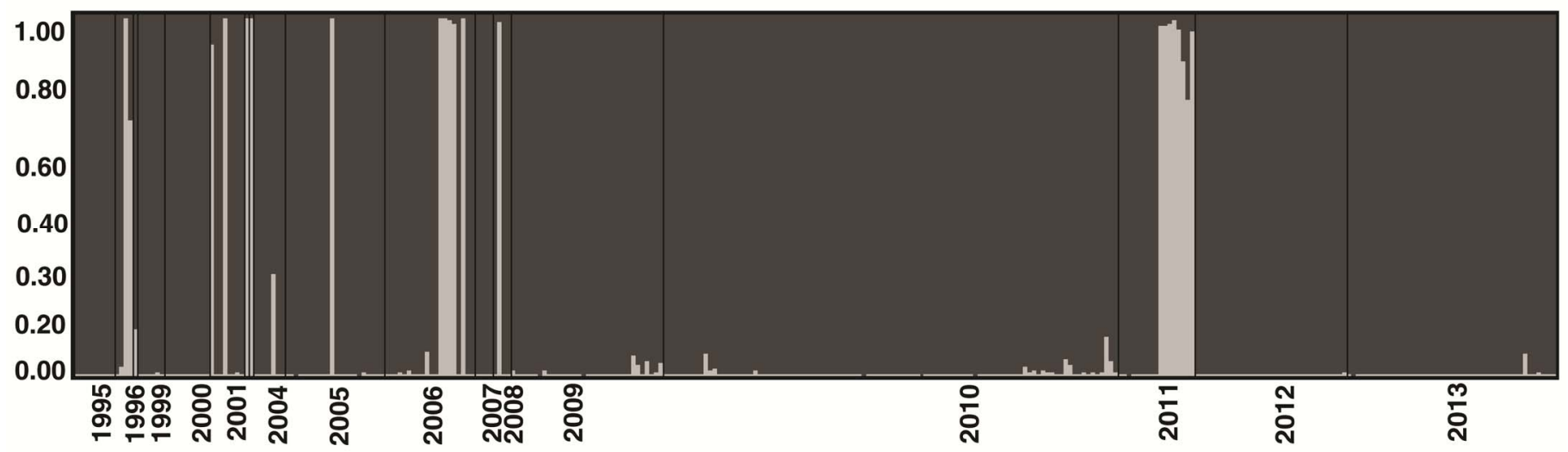

Fig. 1. Population structure of Verticillium dahliae collected from commercial lettuce fields in California inferred using the program STRUCTURE (32). Each individual is represented by a vertical line partitioned into segments that represent the individual's estimated membership fractions in $K$ clusters. The most likely number of genetic clusters was $K=2$.

\begin{tabular}{|l|}
1995 \\
1996 \\
\hline 1997 \\
\hline 1999 \\
\hline 2000 \\
\hline 2001 \\
\hline 2002 \\
\hline 2003 \\
\hline 2004 \\
\hline 2005 \\
\hline 2006 \\
\hline 2007 \\
\hline 2008 \\
\hline 2009 \\
\hline 2010 \\
\hline 2011 \\
\hline 2012 \\
2013 \\
\hline
\end{tabular}

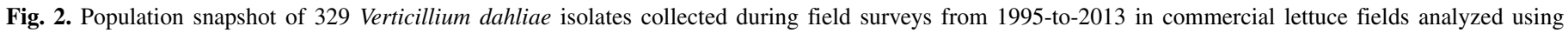

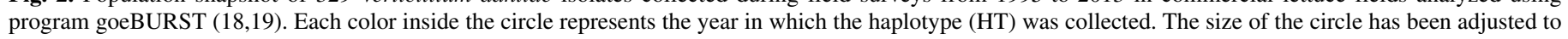
the number of isolates within each HT. Only HTs having more than six isolates are indicated in the figure. 
lates or their sampling year. Most of the $V$. dahliae isolates demonstrated strong affiliation to one of the two clusters identified, and very few admixed individuals were detected. The two clusters differed in only two to three microsatellite alleles. Isolates belonging to both clusters were present in almost all years (1995 to 2013) and more interestingly, isolates belonging to only the light gray cluster were recovered from just the more contemporary (2006 and 2010) samples. In line with the results from the STRUCTURE analyses, we detected a large clonal complex with several hypothetically related HTs in the goeBURST analysis. Nearly $61.70 \%$ of the total isolates were members of microsatellite type HT1, a hypothetical founder type, which was frequently detected in multiple years and locations. In addition to HT1, there were six other predominant HTs (HT2, HT9, HT13, HT17, HT31, and HT32) that were recovered from multiple years and locations. Sixteen HTs were not joined into any goeBURST clonal complex using the single locus variant algorithm, suggesting the presence of rare, distinct haplotypes. All analyses showed that the $V$. dahliae populations from lettuce were highly clonal.

The results also indicate that unique HTs may have been introduced to these regions every year since 1995. It is also possible that unique genotypes could be the result of genetic drift occurring in large populations of field-established genotypes, though to what extent this is driving evolution remains unclear. It has been demonstrated that they were most likely introduced via infected spinach seed $(6,7)$, and this is also supported by the observation that isolates from both spinach seed and lettuce do share identical 13-locus HTs (e.g., the allelic profile 384-299376-301-263-545-333-330-367-289-401-250-277, in the loci order VD2-VD1-VD9-VD11-VD92-VD97-VD69-VD12-VD27VD73-VD8-VD10-VD3, which is found in V. dahliae from both lettuce and spinach seed). In lettuce, we detected 51 distinct MTs that were unique to each of the collection years subsequent to 1995. On average, three novel HTs were recovered each year from these areas, relative to the known diversity from previous years. Interestingly, the highest numbers of unique HTs were collected in 2006, 2009, and 2010, indicating introductions during these years. In some cases, certain HTs detected in earlier years were not observed in subsequent samples, which could reflect the random loss of some genotypes due to stochastic fluctuations in population size or a sampling artifact $(20,40)$. Rare genotypes may be more vulnerable to genetic drift and so have a higher chance of becoming extinct, which may explain their disappearance from local populations (40). Millions of dollars' worth of soil fumigants are repeatedly used in these areas to control this destructive pathogen. However, the dominant genotype (HT1) that was detected in older samples was also present in the contemporary samples, suggesting that these infested fields served as a source of HT1, and infested equipment and personnel may have spread it to other fields prior to fumigation, and thus, HT1 persisted between fields and years. Previous studies have demonstrated that soil fumigations cannot completely eliminate $V$. dahliae microsclerotia from the soil, and some of these microsclerotia remain viable and are able to recolonize subsequent crops (41).
However, soil fumigants may decrease the genetic diversity by eradicating some rare HTs, since 51 distinct HTs detected in this study were recovered from only single years and were never recovered in subsequent years.

Race structure in $V$. dahliae lettuce populations was associated with the geographic locations studied. All of the $V$. dahliae race 2 isolates characterized here were recovered from Watsonville, whereas all of the $V$. dahliae race 1 isolates were from Salinas. Similar patterns of race structure occurs in crops, such as olive, in which $V$. dahliae isolates from Malta belonged to race 2, while isolates from Italy belonged to race 1 (34). Among the samples collected from three commercial lettuce fields in Salinas, all isolates belonged to race 1 and was supported further by observations in the field in which race 1-resistant lettuce cultivars showed no symptoms in Salinas, whereas the same cultivars developed various degrees of Verticillium wilt in Watsonville (R. Hayes, personal communication). Sampling artifacts leading to low recovery of race 2 in certain areas are unlikely, as the sample size from Salinas $(N=146)$ was likely large enough to minimize the effects of nonrandom sampling. Another likely explanation could be that, although race 2 isolates have been introduced into commercial lettuce fields via infected spinach seed, they have not yet established to a level that causes significant yield loss in lettuce in some areas. The threshold inoculum density required for Verticillium wilt to occur on lettuce has been determined to be $>100$ microsclerotia $\mathrm{g}^{-1}$ of soil (5). This scenario is likely because we have been trying to establish a field site infested with only the race 2 isolates of $V$. dahliae for screening breeding materials. Lettuce seedlings inoculated multiple times with $V$. dahliae race 2 planted consecutively for 2 years in this field failed to infest the soil to a level that supports Verticillium wilt development consistently on the susceptible lettuce cultivar, Salinas. It is possible that race 2 isolates have a lower reproductive potential on infected plants compared with race 1 isolates.

Asexual reproduction plays a key role in disease epidemics in lettuce fields in California. The presence of significant gametic linkage disequilibrium in the multilocus dataset of the lettuce isolates collected during 1995 to 2013 suggests that asexual reproduction common in $V$. dahliae $(11,31)$ also occurs in populations from lettuce. Furthermore, the observed multilocus linkage disequilibrium in samples from three commercial lettuce fields suggests that asexual reproduction was the likely means of reproduction. Even though $V$. dahliae is a heterothallic fungus (37), mating type idiomorphs were heavily skewed towards MAT1-2-1 in this study, as only one isolate collected during 2007 had the MAT1-1-1 idiomorph. Clonal reproduction in V. dahliae populations in lettuce fields is very similar to other heterothallic plant pathogens such as Phytophthora species $(25,40)$ and Cryphonectria parasitica (28).

The temporal and spatial structure of pathogen populations in the phytopathological literature is infrequent even though this information is critical for breeding host resistance. Continued genotyping of $V$. dahliae from lettuce fields of California will be necessary to discover the common and novel genotypes, their race

TABLE 3. Genetic diversity of Verticillium dahliae collected from three commercial lettuce fields in California

\begin{tabular}{|c|c|c|c|c|c|c|c|c|c|c|}
\hline Year & $\begin{array}{l}\text { Sample } \\
\text { size }\end{array}$ & $\begin{array}{c}\text { Haplotype } \\
\text { within each } \\
\text { field }\end{array}$ & $\begin{array}{l}\text { Unique haplotype } \\
\text { relative to other } \\
\text { two fields }\end{array}$ & $\begin{array}{l}\text { Clonal } \\
\text { fraction }^{\mathrm{a}}\end{array}$ & $\begin{array}{l}\text { Genotypic } \\
\text { richness }^{b}\end{array}$ & $\begin{array}{c}\text { Gene } \\
\text { diversity }^{\mathrm{c}}\end{array}$ & Race 1 & Race 2 & $\begin{array}{c}\text { MAT-1-1-1: } \\
\text { MAT1-2-1 }\end{array}$ & $r B a r D^{\mathrm{d}}$ \\
\hline Field 1 & 71 & 15 & 13 & 0.79 & 0.20 & $0.20(0.08)$ & 71 & 0 & $0: 71$ & $0.088^{* *}$ \\
\hline Field 2 & 45 & 6 & 2 & 0.87 & 0.11 & $0.22(0.07)$ & 45 & 0 & $0: 45$ & $0.222^{* *}$ \\
\hline Field 3 & 30 & 6 & 2 & 0.80 & 0.17 & $0.20(0.07)$ & 30 & 0 & $0: 30$ & $0.090^{* *}$ \\
\hline
\end{tabular}

${ }^{a}$ Clonal fraction was calculated as $1-$ [(number of different haplotypes)/(total number of isolates)] (43).

b Genotypic richness was calculated as (number of unique haplotypes -1$) /($ number of total isolates -1$)$.

c Unbiased estimate of gene diversity (30).

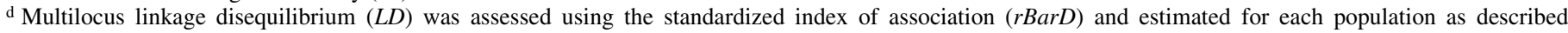
previously (1). The significance of $r$ BarD was tested with 999 randomizations of the data by comparing the observed value to that expected under the null hypothesis of $r B a r D=0$. The null hypothesis of $L D$ was rejected if $P<0.001$. ** indicates significant at $P=0.001$. 
structure and the introduction events. The research reported here has highlighted the importance of understanding the population structure of $V$. dahliae for developing host resistance, the clonal expansion of $V$. dahliae populations from lettuce, the greater recovery of race 1 relative to race 2 isolates, and asexual reproduction of the principal mode of reproduction in $V$. dahliae based on the prevalence of MAT1-2-1 idiomorph and the significant linkage disequilibrium. Finally, the recovery of the highest number of unique HTs from the more recent samples suggests contemporary introductions of these novel HTs into lettuce fields in California. Appearance of novel HTs may also result from mutations in the $V$. dahliae populations over time within a field and follow-up studies to confirm or discount this possibility are currently underway.

\section{LITERATURE CITED}

1. Agapow, P. M., and Burt, A. 2001. Indices of multilocus linkage disequilibrium. Mol. Ecol. Notes 1:101-102.

2. Almany, G. R., De Arruda, M. P., Arthofer, W., Atallah, Z. K., Beissinger, S. R., Berumen, M. L., Bogdanowicz, S. M., Brown, S. D., Bruford, M. W., Burdine, C., Busch, J. W., Campbell, N. R., Carey, D., Carstens, B. C., Chu, K. H., Cubeta, M. A., Cuda, J. P., Cui, Z. X., Datnoff, L. E., Davila, J. A., Davis, E. S., Davis, R. M., Diekmann, O. E., Eizirik, E., Fargallo, J. A., Fernandes, F., Fukuda, H., Gale, L. R., Gallagher, E., Gao, Y. Q., Girard, P., Godhe, A., Goncalves, E. C., Gouveia, L., Grajczyk, A. M., Grose, M. J., Gu, Z. F., Hallden, C., Harnstrom, K., Hemmingsen, A. H., Holmes, G., Huang, C. H., Huang, C. C., Hudman, S. P., Jones, G. P., Kanetis, L., Karunasagar, I., Keyghobadi, N., Klosterman, S. J., Klug, P. E., Koch, J., Koopman, M. M., Koppler, K., Koshimizu, E., Krumbock, S., Kubisiak, T., Landis, J. B., Lasta, M. L., Lee, C. Y., Li, Q. Q., Li, S. H., Lin, R. C., Liu, M., Liu, N., Liu, W. C., Liu, Y., Loiseau, A., Luan, W. S., Maruthachalam, K. K., McCormick, H. M., Mellick, R., Monnahan, P. J., Morielle-Versute, E., Murray, T. E., Narum, S. R., Neufeld, K., de Nova, P. J. G., Ojiambo, P. S., Okamoto, N., Othman, A. S., Overholt, W. A., Pardini, R., Paterson, I. G., Patty, O. A., Paxton, R. J., Planes, S., Porter, C., Pratchett, M. S., Puttker, T., Rasic, G., Rasool, B., Rey, O., Riegler, M., Riehl, C., Roberts, J. M. K., Roberts, P. D., Rochel, E., Roe, K. J., Rossetto, M., Ruzzante, D. E., Sakamoto, T., Saravanan, V., Sarturi, C. R., Schmidt, A., Schneider, M. P. C., Schuler, H., Serb, J. M., Serrao, E. T. A., Shi, Y. H., Silva, A., Sin, Y. W., Sommer, S., Stauffer, C., Strussmann, C. A., Subbarao, K. V., Syms, C., Tan, F., Tejedor, E. D., Thorrold, S. R., Trigiano, R. N., Trucco, M. I., Tsuchiya-Jerep, M. T. N., Vergara, P., van de Vliet, M. S., Wadl, P. A., Wang, A. M., Wang, H. X., Wang, R. X., Wang, X. W., Wang, Y., Weeks, A. R., Wei, F. W., Werner, W. J., Wiley, E. O., Williams, D. A., Wilkins, R. J., Wisely, S. M., With, K. A., Wu, D. H., Yao, C. T., Yau, C., Yeap, B. K., Zhai, B. P., Zhan, X. J., Zhang, G. Y., Zhang, S. Y., Zhao, R., and Zhu, L. F. 2009. Permanent genetic resources added to Molecular Ecology Resources database 1. May 2009-31 July 2009. Mol. Ecol. Resour. 9:1460-1466.

3. Anonymous. 2011. USDA-NASS. http://www.nass.usda.gov/Publications/ Ag_Statistics/2011/index.asp

4. Anonymous. 2012. Agricultural Commissioner's Office Monterey Country Crop Report 2011.

5. Atallah, Z. K., Hayes, R. J., and Subbarao, K. V. 2011. Fifteen years of Verticillium wilt of lettuce in America's salad bowl: A tale of immigration, subjugation, and abatement. Plant Dis. 95:784-792.

6. Atallah, Z. K., Maruthachalam, K., du Toit, L., Koike, S. T., Davis, R. M., Klosterman, S. J., Hayes, R. J., and Subbarao, K. V. 2010. Population analyses of the vascular plant pathogen Verticillium dahliae detect recombination and transcontinental gene flow. Fungal Genet. Biol. 47:416-422.

7. Atallah, Z. K., Maruthachalam, K., and Subbarao, K. V. 2012. Sources of Verticillium dahliae affecting lettuce. Phytopathology 102:1071-1078.

8. Atallah, Z. K., Maruthachalam, K., Vallad, G. E., Davis, R. M., Klosterman, S. J., and Subbarao, K. V. 2011. Analysis of Verticillium dahliae suggests a lack of correlation between genotypic diversity and virulence phenotypes. Plant Dis. 95:1224-1232.

9. Berbegal, M., Garzón, C. D., Ortega, A., Armengol, J., Jiménez-Díaz, R. M., and Jiménez-Gasco, M. M. 2011. Development and application of new molecular markers for analysis of genetic diversity in Verticillium dahliae populations. Plant Pathol. 60:866-877.

10. Berbegal, M., Ortega, A., Jiménez-Gasco, M. M., Olivares-García, C., Jiménez-Díaz, R. M., and Armengol, J. 2010. Genetic diversity and host range of Verticillium dahliae isolates from artichoke and other vegetable crops in Spain. Plant Dis. 94:396-404.

11. Collado-Romero, M., Mercado-Blanco, J., Olivares-García, C., ValverdeCorredor, A., and Jiménez-Díaz, R. M. 2006. Molecular variability within and among Verticillium dahliae vegetative compatibility groups determined by fluorescent amplified fragment length polymorphism and polymerase chain reaction markers. Phytopathology 96:485-495.

12. de Jonge, R., Bolton, M., Kombrink, A., van den Berg, G., Yadeta, K., and Thomma, B. 2013. Extensive chromosomal reshuffling drives evolution of virulence in an asexual pathogen. Genome Res. 23:1271-1282.

13. de Jonge, R., van Esse, H. P., Maruthachalam, K., Bolton, M. D., Santhanam, P., Saber, M. K., Zhang, Z., Usami, T., Lievens, B., and Subbarao, K. V. 2012. Tomato immune receptor Vel recognizes effector of multiple fungal pathogens uncovered by genome and RNA sequencing. Proc. Natl. Acad. Sci. USA 109:5110-5115.

14. Dilmaghani, A., Gladieux, P., Gout, L., Giraud, T., Brunner, P. C., Stachowiak, A., Balesdent, M. H., and Rouxel, T. 2012. Migration patterns and changes in population biology associated with the worldwide spread of the oilseed rape pathogen Leptosphaeria maculans. Mol. Ecol. 21:2519-2533.

15. du Toit, L. J., Derie, M. L., and Hernandez-Perez, P. 2005. Verticillium wilt in spinach seed production. Plant Dis. 89:4-11.

16. Dung, K. S. J., Peever, T., and Johnson, D. A. 2013. Verticillium dahliae populations from mint and potato are genetically divergent with predominant haplotypes. Phytopathology 103:445-459.

17. Evanno, G., Regnaut, S., and Goudet, J. 2005. Detecting the number of clusters of individuals using the software STRUCTURE: A simulation study. Mol. Ecol. 14:2611-2620.

18. Feil, E. J., Li, B. C., Aanensen, D. M., Hanage, W. P., and Spratt, B. G. 2004. eBURST: Inferring patterns of evolutionary descent among clusters of related bacterial genotypes from multilocus sequence typing data. J. Bacteriol. 186:1518-1530.

19. Francisco, A. P., Bugalho, M., Ramirez, M., and Carriço, J. A. 2009. Global optimal eBURST analysis of multilocus typing data using a graphic matroid approach. BMC Bioinformatics 10:152.

20. Goss, E. M., Larsen, M., Chastagner, G. A., Givens, D. R., and Grünwald, N. J. 2009. Population genetic analysis infers migration pathways of Phytophthora ramorum in US nurseries. PLoS Pathogens 5:e1000583.

21. Hayes, R. J., Maruthachalam, K., Vallad, G. E., Klosterman, S. J., and Subbarao, K. V. 2011. Selection for resistance to Verticillium wilt caused by race 2 isolates of Verticillium dahliae in accessions of lettuce (Lactuca sativa L.). Hortscience 46:201-206.

22. Hayes, R. J., Vallad, G. E., Qin, Q.-M., Grube, R. C., and Subbarao, K. V. 2007. Variation for resistance to Verticillium wilt in lettuce (Lactuca sativa). Plant Dis. 91:439-445.

23. Inderbitzin, P., Bostock, R. M., Davis, R. M., Usami, T., Platt, H. W., and Subbarao, K. V. 2011. Phylogenetics and taxonomy of the fungal vascular wilt pathogen Verticillium, with the descriptions of five new species. PLoS ONE 6:e28341.

24. Inderbitzin, P., Davis, R. M., Bostock, R. M., and Subbarao, K. V. 2013. Identification and differentiation of Verticillium species and $V$. longisporum lineages by simplex and multiplex PCR assays. PLoS ONE 8:e65990.

25. Linde, C., Drenth, A., and Wingfield, M. J. 1999. Gene and genotypic diversity of Phytophthora cinnamomi in South Africa and Australia revealed by DNA polymorphisms. Eur. J. Plant Pathol. 105:667-680.

26. McDonald, B. A., and Linde, C. 2002. Pathogen population genetics, evolutionary potential, and durable resistance. Annu. Rev. Phytopathol. 40:349-379.

27. McDonald, B. A., and McDermott, J. M. 1993. Population genetics of plant pathogenic fungi. Bioscience 43:311-319.

28. Milgroom, M. G., Sotirovski, K., Spica, D., Davis, J. E., Brewer, M. T., Milev, M., and Cortesi, P. 2008. Clonal population structure of the chestnut blight fungus in expanding ranges in southeastern Europe. Mol. Ecol. 17:4446-4458.

29. Nei, M. 1978. Estimation of average heterozygosity and genetic distance from a small number of individuals. Genetics 89:583-590.

30. Peever, T., Salimath, S. S., Su, G., Kaiser, W. J., and Muehlbauer, F. J. 2004. Historical and contemporary multilocus population structure of Ascochyta rabiei (teleomorph: Didymella rabiei) in the Pacific Northwest of the United States. Mol. Ecol. 13:291-309.

31. Pegg, G. F., and Brady, B. L. 2002. Verticillium Wilts. CABI Publishing, New York, NY.

32. Pritchard, J. K., Stephens, M., and Donnelly, P. 2000. Inference of population structure using multilocus genotype data. Genetics 155:945-959.

33. Rosenberg, N. A. 2004. DISTRUCT: A program for the graphical display of population structure. Mol. Ecol. Notes 4:137-138.

34. Short, D. P., Gurung, S., Maruthachalam, K., Atallah, Z. K., and Subbarao, K. V. 2014. Verticillium dahliae race 2-specific PCR reveals a high frequency of race 2 strains in commercial spinach seed lots and delineates race structure. Phytopathology doi.org/10.1094/PHYTO-09-130253-R

35. Subbarao, K. V., Hubbard, J. C., Greathead, A. S., and Spencer, G. A. 1997. Verticillium wilt. Pages 26-27 in: Compendium of Lettuce Dis- 
eases. R. M. Davis, K. V. Subbarao, R. N. Raid, and E. A. Kurtz, eds. The American Phytopathological Society, St. Paul, MN.

36. Szpiech, Z. A., Jakobsson, M., and Rosenberg, N. A. 2008. ADZE: A rarefaction approach for counting alleles private to combinations of populations. Bioinformatics 24:2498-2504.

37. Usami, T., Itoh, M., and Amemiya, Y. 2009. Asexual fungus Verticillium dahliae is potentially heterothallic. J. Gen. Plant Pathol. 75:422-427.

38. Usami, T., Itoh, M., Morii, S., Miyamoto, T., Kaneda, M., Ogawara, T., and Amemiya, Y. 2012. Involvement of two different types of Verticillium dahliae in lettuce wilt in Ibaraki Prefecture, Japan. J. Gen. Plant Pathol. 78:348-352.

39. Vallad, G. E., Qin, Q.-M., Grube, R., Hayes, R. J., and Subbarao, K. V. 2006. Characterization of race-specific interactions among isolates of Verticillium dahliae pathogenic on lettuce. Phytopathology 96:1380-1387.
40. Vercauteren, A., De Dobbelaere, I., Grünwald, N., Bonants, P., Van Bockstaele, E., Maes, M., and Heungens, K. 2010. Clonal expansion of the Belgian Phytophthora ramorum populations based on new microsatellite markers. Mol. Ecol. 19:92-107.

41. Wu, B. M., Koike, S. T., Vallad, G. E., and Subbarao, K. V. 2008. Postfumigation horizontal and vertical recolonization of soil by Verticillium dahliae. (Abstr.) Phytopathology 98(suppl.):S173.

42. Yeh, F. C., and Boyle, T. J. B. 1997. Population genetic analysis of codominant and dominant markers and quantitative traits. Belg. J. Bot. 129:157.

43. Zhan, J., Kema, G., Waalwijk, C., and McDonald, B. 2002. Distribution of mating type alleles in the wheat pathogen Mycosphaerella graminicola over spatial scales from lesions to continents. Fungal Genet. Biol. 36: $128-136$ 